\title{
Perspective on Crude Palm Oil Production: The Effect of Raw Palm Oil and Biofuel Prices
}

\author{
Afriany, Rubianto Pitoyo \\ Universitas Putra Indonesia YPTK Padang, Indonesia \\ email : afriany@upiyptk.ac.id
}

\begin{abstract}
Efficiency is the important things in production process. Some production factors as labor, materials, and machinery must be calculate accurately. The purpose of this research is for analyzing the influence of raw palm oil and Biofuel prices against crude palm oil production. Sample in this research is time series data that specialized production data, The technique analysis is using analysis of multiple linier regression. The results from analysis show correlation between raw palm oil and biofuel prices with crude palm oil production is $57.1 \%$, The relationship between raw palm oil against crude palm oil production have significant effect and biofuel prices against crude palm oil production have no significant effect. Based on the results of $\mathrm{F}$ test there are the significant influence between raw palm oil and biofues prices against crude palm oil production. finding in this research is PT. Wilmar using 3 type of fuel for production process, petroleum, biofuel and waste of raw palm oil production which makes biofuel prices have no effect on crude palm oil production
\end{abstract}

Keywords: Raw Palm Oil, Biofuel Prices, Crude Palm Oil. Production JEL Classification : L11, Q14, P28

\section{Introduction}

Coconut palm as the plant which produce Crude Palm Oil and the core palm (Kernel Palm Oil) is one of plantation commodity which become source of producing foreign exchange non oil and gas for Indonesia. Demand of Crude Palm Oil each year continues to increased because of the the widespread utilization, not just for the consumption needs, but already utilized as the material the basic for drugs and cosmetic.

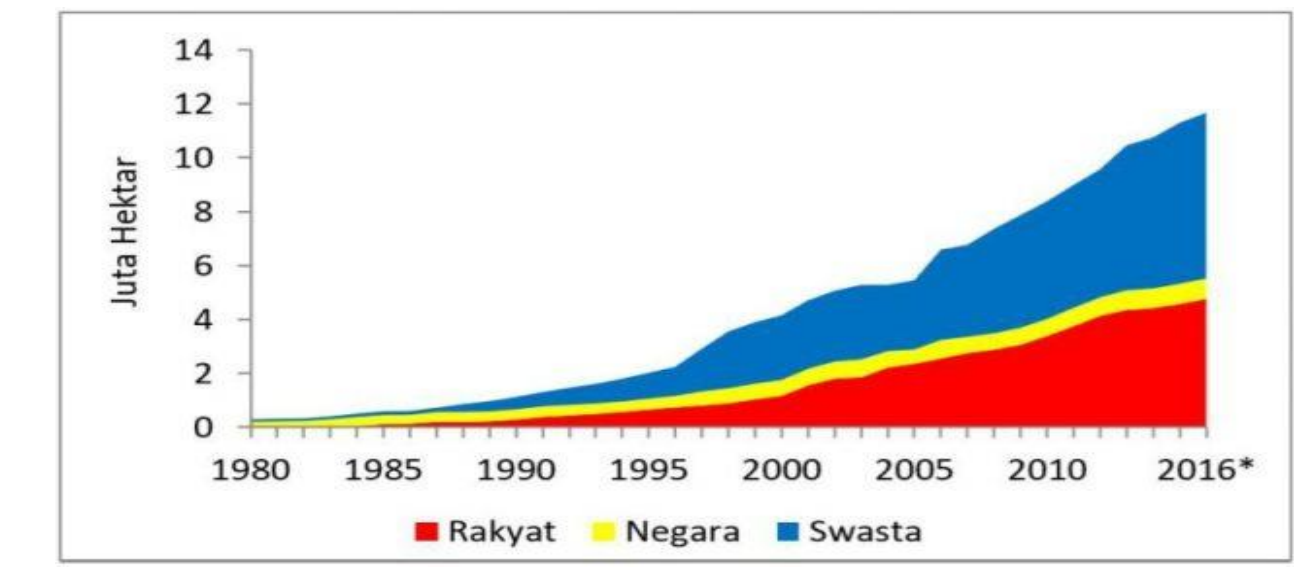

Source : Kementerian Pertanian.2018

Figure 1. Development Palm Oil Plantation areas

Figure 1. show development interest invest on plantation coconut palm. Since 2004 market share of Crude Palm Oil from year to year also continues to increased and has occupy the order first as supplier the main vegetable oil in the world. Indonesia and Malaysia is the biggest and dominated on supply of Crude Palm Oil. Even from the side production, Indonesia and Malaysia supplies less more 90 percent Crude Palm Oil production in the world. 

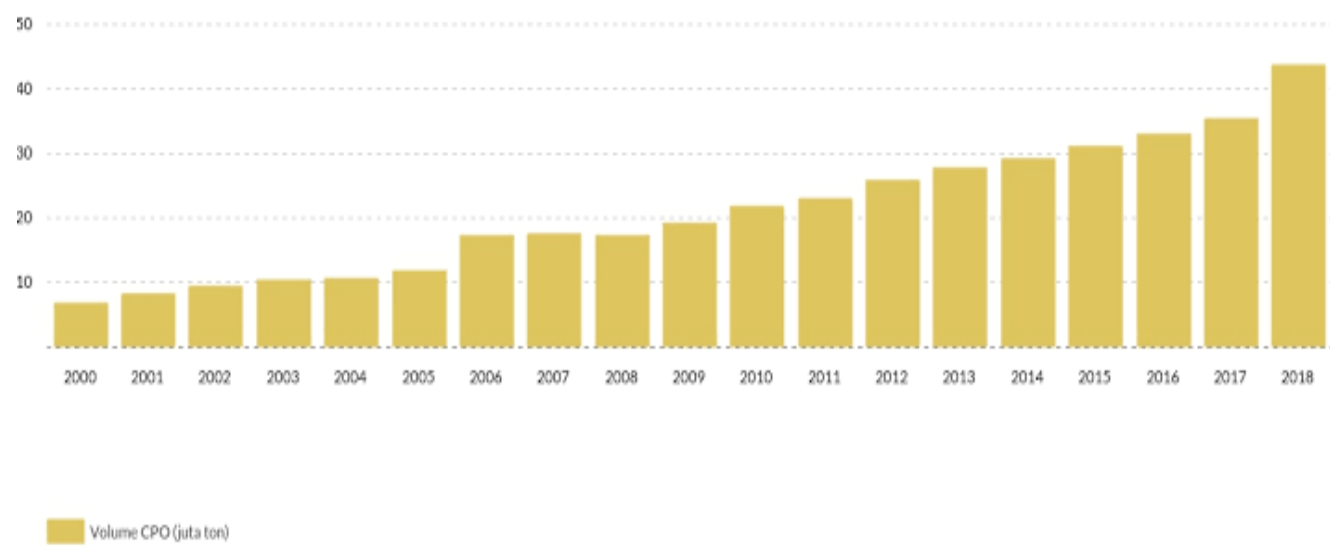

Source : Direktorat Jendral Perkebunan.2019

Figure 2. Crude Palm Oil Production Volume In Indonesia

Fluctuations price in the domestic market are inseparable from the influence of the level of Crude Palm Oil production, stock policy and level consumption world Crude Palm Oil. Change of Crude Palm Oil demand in international market will influence structure price, then changes in world Crude Palm Oil prices will affect production as well as Indonesia's Crude Palm Oil export offerings including the economy Indonesia in general. (Azwar, 2015). With the very fertile region, Indonesia becomes one of the biggest country in world which produce Crude Palm Oil. With this condition makes Indonesia possible to produce alternative source energy that originated from palm oil.

Because of the recent price increase in crude oil and growing environmental concerns, biodiesel has become an important alternative fuel that acts as the lifeblood of the retailing industries that are highly depended on the logistics and transportations to deliver their goods on time. (Kantaporn, Aree, Songsak and Chukiat. 2012)

Indonesia's CPO production reached 45.86 million tons in 2019. By 2025, BBN production is targeted to reach 13.8 million kilo liters. Indonesian environmentalists even refer to CPO-based biofuels (BBN) as one of its flagship programs through mandatory B-20 and B-30 policies. The implementation of the obligation to mix diesel or diesel fuel with FAME (Fatty Acid Methyl Ester) or mandatory B-30 is considered to save the country foreign exchange by US $\$ 4.8$ billion or Rp67.2 trillion, increase the value added CPO by Rp63.39 trillion, absorb 1.2 million workers, and reduce 14.25 million tons of $\mathrm{CO} 2$ (carbon dioxide) emissions.

Of course, biodiesel projects need to be committed by stakeholders such as regulators, BPDP (Plantation Fund Management Agency) of Palm Oil, Indonesian Biofuel Producers Association (Aprobi), to Pertamina as well as other oil and gas producers. Chairman of the Indonesian Palm Oil Farmers Association (Apkasindo) Gulat Medali Emas Manurung revealed the B-30 program encourages domestic demand. After the B-30 mandatory policy, domestic uptake increased from $18 \%$ to $25 \%$. During 2015-2019, BPDP has raised Rp51 trillion. Of these, 33.6 trillion rupiah has been distthousandted for various needs, including biodiesel incentives totaling 30.2 trillion rupiah. Now, the incentives BPDP pays to producers have the potential to swell. Moreover, the price of $\mathrm{CPO}$ has decreased. Several options can be taken by the government to reduce BPDP burden such as the use of association member funds, increased tariffs on export levies, disanment of government funds and increasing the price of biodiesel sold to the public.

Table 1 Biodiesel production, distthousandtion and export

\begin{tabular}{|l|l|l|l|}
\hline Year & Production & Distthousandtion & Export \\
\hline 2015 & 1,65 million $\mathrm{kl}$ & 915,5 thousand $\mathrm{kl}$ & 328,6 thousand $\mathrm{kl}$ \\
\hline
\end{tabular}


Jurnal EKOBISTEK, Vol.10, No. 1. Januari 2021, Hal 15-25, ISSN : 2301-5268 | E-ISSN : 2527-9483

Copyright@2021 6y LPPM VPI YPTK Padang

\begin{tabular}{|l|l|l|l|}
\hline 2016 & 3,65 million $\mathrm{kl}$ & 3,00 million $\mathrm{kl}$ & 476,9 thousand $\mathrm{kl}$ \\
\hline 2017 & 3,41 million kl & 2,57 million $\mathrm{kl}$ & 187,3 thousand $\mathrm{kl}$ \\
\hline 2018 & 6,16 million kl & 3,75 million $\mathrm{kl}$ & 1,82 million $\mathrm{kl}$ \\
\hline 2019 & 8,39 million $\mathrm{kl}$ & 6,39 million $\mathrm{kl}$ & 1,31 million $\mathrm{kl}$ \\
\hline
\end{tabular}

(Sumber: Aprobi)

Table 1 shows a comparison between domestic use and biodiesel exports due to the government's mandatory policy

The results of the analysis from Rambe, Kusnadi and Suharno (2019) which used data from various related agencies such as the Central Bureau of Statistics, Ministry of Agriculture, BAPPEBTI, World Bank and other institutions related to this research which are analyzed by dynamic system models show that the development of Indonesian biodiesel has not been able to meet the level of the blending rate according to mandatory biodiesel. Efforts to increase the achievement of the blending rate level can be done by providing biodiesel subsidies. Export duty policy is also needed in an effort to maintain the stability of domestic CPO prices and the price of palm cooking oil.

Pt. Wilmar Nabati is the largest biofuel producer in West Sumatra. With Mandatory policy and export tax rate make PT. Wilmar Nabati using 3 types of source energy in the production process. In addition using Petroleum and biodiesel as main fuel for run machinery, PT. Wilmar Nabati using also fuel from waste of Raw Palm Oil production with the composition of the $24 \%$ from prices Raw Palm Oil. This aims to increase the cost efficiency of production resulting from biodiesel usage policy.

According to Lumbantoruan, Poerwanto, Tarigan (2013), one of the methods that can be used in planning cpo production planning is the mathematical method of goal programming. The difference between goal programming method and linear programming method is that it can handle the problem of optimal allocation or optimum combination of several opposing problems. Thus the decision taken is a satisfactory result of some of the alternatives offered. The decision variable stipulated in this study was the amount of CPO production in each month during the period 2012. As for the target constraints used in the data processing process are minimizing production costs, minimizing TBS procurement costs, maximum CPO production, CPO demand, TBS availability, TBS processing goals and processing time availability. Forecasting the number of requests is analyzed from the sales data of the previous period by using the kuadratis method. Goal programming approach conducted using the help of Linear Interactive Discrete Optimizer (LINDO) program.

Based on research Maygirtasari, Yulianto and Mawardi (2015) knows that prices Crude Palm Oil domestic have the biggest value of the coefficient beta, so prices Crude Palm Oil domestic have strong influence, then prices Crude Palm Oil domestic have dominant influence against volume of Indonesia Crude Palm Oil export. In line with the results form Ewaldo (2015), that the production of Indonesia Crude Palm Oil had significant positive influence to volume of Indonesia Crude Palm Oil export.

On production process, materials known as main input for transforming input become output. Quality of the outputs depends on the quality of inputs. The more quality of coconut palm fruit will produce high quality materials of crude palm oi production.

Moreover Kewinoto and Sjahruddin (2015) research results show, there are two independent variables that have an influence on the stock price on plantations producing palm oil (Crude Palm Oil) are: Price Crude Palm Oil and Sales Volume, while the other two independent variables, namely inflation and the exchange rate has no significant effect on the stock price on plantations producing palm oil (Crude Palm Oil). With the high price of palm oil, it influences more capital for investment and recruitment of labor to increase the production of palm oil. Since the price of palm oil is determined by many factors, the factor that influences palm oil prices is the availability of 
substitutes such as the prices of soybean oil. The price of crude oil is also an important factor that influences palm oil prices.

Biodiesel is a mono alkyl ester compound which produced through a tranesterification reaction between triglycerides and methanol become methyl esters and glycerol with help of basic catalysts. Triglycerides is well known as oil from fruit. The process of esterification and transesterification Crude Palm Oil it turns out able to produce the fuels material. The fuels material from Crude Palm Oil more eco-friendly environment because free nitrogen and sulfur. In addition to it the content of acid oleic yang achieve $55 \%$ in oil palm pretty as the material consideration for using oil palm as the material raw making the material fuel vegetable (Nugroho, 2014).

The process that has been done to produce biofuels such as thermal cracking that takes place at high temperatures and pressures that cause great energy needs, so that is currently developed the process of renal engkahan. The process can convert vegetable oil into alternative fuels (biofuels). Hydrocracking is a process of storytelling by reacting vegetable oils with a certain amount of hydrogen gas under certain temperature and pressure conditions. Products from the hydrocracking method will be produced biofuels in the form of straight chain liquid alkanes from C-15 to C-18. This hydrocracking process has its advantages and disadvantages. In terms of advantages, this process can provide high conversion, yield towards middle distillate is also high, the resulting alkane quality has a high number of setana. In terms of weaknesses, this process requires considerable energy because hydrocracking operates at high temperatures and pressures, requiring special equipment, determination of the right reaction conditions (catalyst type, catalyst preparation, temperature, pressure and reaction time). (Nugroho, Fitriyanto, Roesyadi:2014) In the period 2009-2014, the program received subsidies from the State Budget. A number of palm oil export companies with the government designed fundraising programs and formed the Plantation Fund Management Agency (BPDP). This fund is used to increase state, farmer, and private income, while re-running the $\mathrm{BBN}$-biodiesel liability program, replanting, research, promotion, and advocacy. In the case of the BBN-biodiesel liability program, funds are used one of them to pay the difference in the price on the vegetable fuel purchased by Pertamina. The price difference arises because Pertamina only wants to pay for the purchase in accordance with the price of diesel. Meanwhile, the BBN-biodiesel program funds are used to pay companies that produce biodiesel and sell it to Pertamina.

In accordance with Regulation of the Minister of Energy and Mineral Resources (ESDM) No. 41 of 2018 on the Provision and Utilization of Biodiesel Type Vegetable Fuels within the Framework of Financing by the Palm Oil Plantation Fund Management Agency, palm oil incentives or biodiesel financing funds are used to cover the less difference between HIP Solar oil and HIP biodiesel. New incentives will be given to biodiesel producers if HIP biodiesel is higher than HIP solar oil. The price of HIP BBN for this type of biodiesel is calculated using hip formula $=($ Average $\mathrm{CPO} \mathrm{KPB}+$ $100 \mathrm{USD} /$ ton) $\mathrm{x} 870 \mathrm{Kg} / \mathrm{m} 3+$ Transport Cost.

The results of Syahril et all (2019), shows that there is long-term relationship of global Crude Palm Oil price, marketing margins, and palm oil plantations on environmental quality index. For short run, this study found that global Crude Palm Oil price has a significant positive effect on environmental quality index. Meanwhile, the size of palm oil plantation and marketing margins have a significant negative effect on environmental quality index in Indonesia. Also, using the bivariate test, this study proves that there is one way causality relationship between the global Crude Palm Oil prices, marketing margins and size of oil palm area on environmental quality index. In addition, the global Crude Palm Oil prices and marketing margins fluctuations causing shock in environmental quality index.

Based description the above, we interested to research the influence of the Raw Palm Oil and biofuel prices on Crude Palm Oil production with hypothesis as here

$\mathrm{Ha}^{1}$ : Raw Palm Oil have significant effect on Crude Palm Oil production

$\mathrm{Ha}^{2}$ : Biofuel Prices have significant effect on Crude Palm Oil production

$\mathrm{Ha}^{3}$ : Raw Palm Oil and Biofuel price have significant effect on Crude Palm Oil production 


\section{Research methods}

The design research is quantitative and associative method, quantitative method is systematic scientific research against a parts and phenomenas with the all relationships. The purpose research quantitative is to develop and using mathematical models, theorytheory and hypothesis which is corrrelatted with the natural phenomena. Quantitative research used for test a theory and for show the relationship between variables. Associative/causal research is the research which use for analyzing the relationship between variables or how a variable affect other variables. In this research data and information obtained with time series data

According to Anggoro (2008) population is all data which will to be attention in a scopes and specific time that we define. This research use data from the population which all source on year 2017 until 2018 on PT. Wilmar Nabati. According to Nugroho (2005) Sample is most member of the from the population which selected with using specific procedure to be expected can represent the population, is most from subject research which selected and is considered representing the the overall.

So based on understanding the above, sample from this research is data Raw Palm Oil, prices Biofuels and data production from PT. Wilmar Nabati.

Variable is a the concepts which have a variation value, and can be describe into independent variable and dependent variable, in this research, we use 2 (two) independent variables and 1 (one) dependent variable

As for the definition for these three variables that are following:

1. Production Crude Palm Oil

Production Crude Palm Oil concerns the process of the transformation of input (commodity palm) be output (Crude Palm Oil), which the results is production of Crude Palm Oil unit with period year 2017 - 2018

2. Raw Palm Oil

Raw Palm Oil is the main material which used for produce Crude Palm Oil. Raw Palm Oil is bunches of cocconut palm fruits in Kg/unit with period year 2017 - 2018

3. Biofuel Prices

Biofuel Prices is a the value of money exchanged for getting the benefits and having or using that energy for running the activity of production process, where Biofuels prices which used is period $2017-2018$.

Multiple Linier Regression Analysis

Used for analyze the influence of independent variables against dependent variable. In this research is for analyze the influence of Raw Palm Oil and Biofuel prices against Crude Palm Oil production with the formula:

$$
\mathrm{Y}=\mathrm{a}+\mathrm{bt} \mathrm{X} 1+\mathrm{b} 2 \mathrm{X} 2+\mathrm{e}
$$

$$
\begin{aligned}
& \text { Wheres } \quad \mathrm{Y}=\text { Crude Palm Oil Production } \\
& \mathrm{X}_{1}=\text { Raw Palm Oil } \\
& \mathrm{X}_{2}=\text { Biofuel prices } \\
& \mathrm{A}=\text { Constanta } \\
& \mathrm{b}_{1}, \mathrm{~b}_{2}=\text { Regresion coeffisient } \\
& \mathrm{e}=\text { Dummy variabel }
\end{aligned}
$$

According to Sugiyono (2007) Analysis of correlation used to knowing influence or relationship between independent variable and dependent variable. Correlation analysis aims for measure the strength of linier relationship between two variables. Correlation not showing the functional relationship or with the other word, correlation is not distinguish dependent variable with independent variable. The coefficient determination on the point is measure the how much ability from the regression model in explain a variation of dependent variable, value of the coefficient determination is between zero and one. The value of the $\mathrm{R}^{2}$ which small means the ability independent variable in explain a variation of dependent variable is very limited, while if $R$ 
value approaching to one, that's means independent variables ability to explain the variation of dependent variable is very high.(Ghozali,2006)

\section{Results and Discussion}

\section{Crude Palm Oil Production}

The process of production is start with separate bunches of the coconut palm fruit with the fruits. The results the separation is produce $66 \%$ the coconut palm fruits and $34 \%$ empty of bunches. The next stage is separate shell and fibers from the coconut palm fruits. In addition, fibers and shell from the coconut palm fruits will be processed then. Fibers will squeezed for produce raw Crude Palm Oil with the composition of the results by 15\%, and shell from coconut palm fruits will processed for taken the core from fruit which named Kernel with the composition of the results by $14 \%$. The rest of the waste production on stage this is by $15 \%$. On the next stage is processing Kernel. shell from the coconut palm fruits will processed for produce Kernel, on this process there are rest of the waste by $9 \%$ and just $5 \%$ to become Kernel. In the conclusion, from the composition of the $100 \%$ Bunches of the fruit fresh generated Crude Palm Oil by $21 \%$, Kernel by $5 \%$, waste of the process will be use for the fuels material by $24 \%$, and the rest is junks.

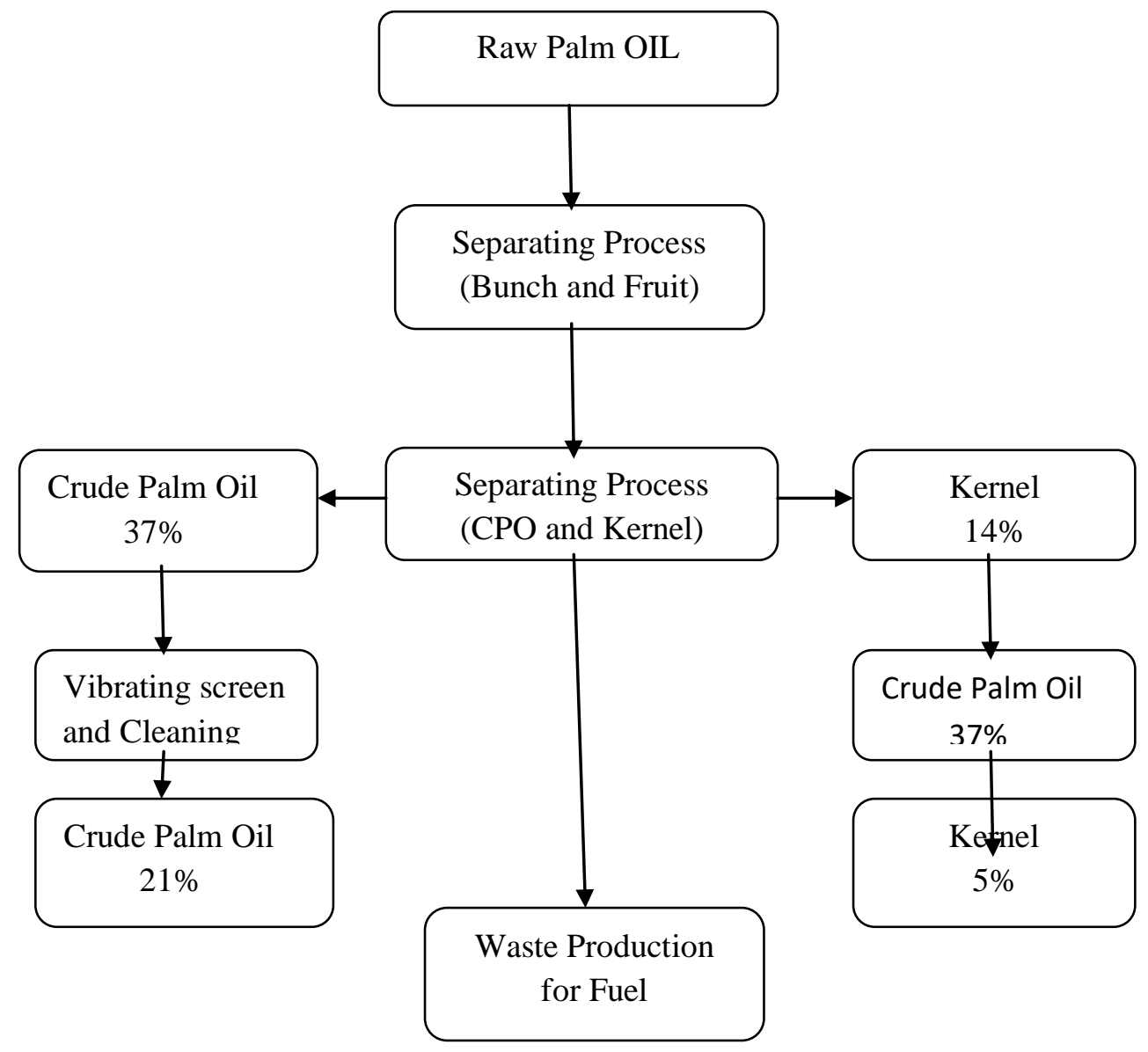

Source : PT Wilmar Nabati,2019

Figure. 4 Crude Palm Oil Production Process

Data Crude Palm Oil production period 2017 - 2018 as follow:

Table 2. Crude Palm Oil and Kernel Production

\begin{tabular}{lrr}
\hline \multicolumn{1}{c}{ Period } & Crude Palm Oil $(\mathrm{Kg})$ & Kernel $(\mathrm{Kg})$ \\
\hline Jan 2017 & 3932183 & 851421 \\
Feb 2017 & 3621406 & 830174 \\
Mar 2017 & 3995914 & 880174 \\
\hline
\end{tabular}




\begin{tabular}{llr}
\hline Apr 2017 & 4436959 & 946487 \\
May 2017 & 4105186 & 889718 \\
Jun 2017 & 3420441 & 728648 \\
Jul 2017 & 3420441 & 847627 \\
Aug 2017 & 4232778 & 723887 \\
Sep 2017 & 3549397 & 1083637 \\
Oct 2017 & 4997432 & 975726 \\
Nov 2017 & 4533962 & 825960 \\
Des 2017 & 3467748 & 939196 \\
Jan 2018 & 4182549 & 862201 \\
Feb 2018 & 3659519 & 879121 \\
Mar 2018 & 3852482 & 1011765 \\
Apr 2018 & 4244926 & 919404 \\
May 2018 & 4166116 & 863349 \\
Jun 2018 & 3910462 & 940899 \\
Jul 2018 & 4061876 & 1140222 \\
Aug 2018 & 3995508 & 983029 \\
Sep 2018 & 4597441 & 1170447 \\
\hline Soure & &
\end{tabular}

\section{Raw Palm Oil}

The purchasing range prices of the raw Crude Palm Oil between Rp.800/Kg until Rp.1912. Fluctuated of prices is rely on the availability of the coconut palm fruits from the palm oil plantations. PT.Wilmar use coconut palm fruits supply distthousandtion from own plantation on division 1-3, PTPN VI, and the public plantation Jambi districst area. Crude Palm Oil price behavior is crucially dependent on both the supply and demand factors. On the supply side, both Crude Palm Oil production and palm oil stock play a significant role in terms of influencing the Crude Palm Oil price behavior. On the demand side, exports of oil palm products is a key factor influencing Crude Palm Oil price behavior. Crude Palm oil price behavior will result in a 'shock' reaction if the element of market sentiment becomes unpredictable. The combination of fundamental and market sentiment factors are considered the 'rule of thumb ' that will determine Crude Palm Oil price equilibrium in the world market. (Rahman, Balu and Faizah, 2015)

Price of Biofuel (X2)

In the process of production Crude Palm Oil, theres 2 kinds of fuel which use for manchinery, Biofuels and waste from Raw Palm Oil. Biofuels produced by the company with the cost of unit/liter with range between Rp. $7.072 \mathrm{~s} / \mathrm{d}$ Rp. 9.348, Biofuels used for turn on generator before the main machine enabled, while the main machine functions for run all production activity. The waste from Raw Palm Oil fuels generated through boiler where is $24 \%$ from unit Raw Palm Oil/Kg. Prices from waste Raw Palm Oil fuel is between range Rp. 216 s/d Rp. 459.

Coefficient Correlation

Table 3. Correlation

\begin{tabular}{lllll}
\hline Model & R & R Square $^{\mathrm{b}}$ & $\begin{array}{l}\text { Adjusted } \\
\text { Square }\end{array}$ & $\begin{array}{l}\text { R Std. Error of the } \\
\text { Estimate }\end{array}$ \\
\hline 1 & $.994^{\mathrm{a}}$ & .988 & .986 & 482608.567
\end{tabular}

Coefficient correlation between Raw Palm Oil and Biofuel price with Crude Palm Oil production is $51.1 \%$. Correlation between Raw Palm Oil and Biofuel price with Crude Palm Oil production is $57.1 \%$, then relationship this correlation could be said 
with strong enough correlation, which Raw Palm Oil and Biofue prices have the influence of by $57,1 \%$ against Crude Palm Oil production.

The Coefficient Determination

Value $\mathrm{R}$ square or the coefficient determination is 0,326 or $32,6 \%$. But because this research has two independent variables then it will use adjusted $R$ square, by 0,251 . This means $25,1 \%$ variance from numbers Crude Palm Oil production can described by a variation variables from Raw Palm Oil and Biofuel prices.

Table 4. Coefficients

\begin{tabular}{|c|c|c|c|c|c|c|c|}
\hline \multirow[b]{2}{*}{ Model } & \multicolumn{2}{|c|}{$\begin{array}{l}\text { Unstandardized } \\
\text { Coefficients }\end{array}$} & \multicolumn{3}{|c|}{$\begin{array}{l}\text { Standardized } \\
\text { Coefficients }\end{array}$} & \multicolumn{2}{|c|}{$\begin{array}{l}\text { Collinearity } \\
\text { Statistics }\end{array}$} \\
\hline & $\mathrm{B}$ & Std. Error & Beta & $\mathrm{t}$ & Sig. & Tolerance & VIF \\
\hline Constant & $3.011 \mathrm{E} 6$ & $1.219 \mathrm{E} 6$ & & 2.470 & .024 & & \\
\hline RawPalm Oil & .085 & .030 & .594 & 2.808 & .012 & .839 & 1.193 \\
\hline Biofuel & -46.674 & 153.032 & -.064 & -.305 & .764 & .839 & 1.193 \\
\hline
\end{tabular}

The equation multiple regression linier can be written as :

$\mathrm{Y}=3.11 .0000,085 \mathrm{X} 1-46.674 \mathrm{X} 2$

Value of 3,001,000 constants, means all things of variables independent is considered constant, hence the value of production Crude Palm Oil is 3,001,000. Score coefficient regression variable Raw Palm Oil 0.085 that

means it if score of Raw Palm Oil increasing one unit, then will upgrade amount of production Crude Palm Oil of 0.085 unit. So also on the contrary if happen a decrease the value of Raw Palm Oil by one unit, then will decrease Crude Palm Oil production by 0.085 unit. Score coefficient regression variable price Biofuel $-46,674$ that means, if an increase in the price of Biofuel is one unit, it will bring down Crude Palm Oil production by 46647 unit. So also on the contrary if happen Biofuel prices decrease by one unit, then will improve Crude Palm Oil production by 46.647 unit.

The value of $t$ test obtained by 2,808 and the value of $t$ table 2,0930 with level significance 0,012, this show that Raw Palm Oil have influence against Crude Palm Oil production and the others variabel, the value of $t$ test obtained is by 0,305 and the value of $\mathrm{t}$ table 2,0930 with level significant by 0,764 , this show that Biofuel prices has no effect against Crude Palm Oil production.

The result from Purba dan Hartoyo (2010) show the demand for CPO is not responsive to changes in the price of the material fuel, in both the short and long term. It is caused by the limited share of exports which can be met by Indonesia, to respond to the demand for biodiesel from Indonesia. Soy oil is a source of biodiesel that is most dominant in the world market with a share of $76 \%$, while exports of biodiesel material the raw CPO is $24 \%$. So the response to do not the elastic. Of $24 \%$, the share Indonesian biodiesel is $18 \%$ and Malaysia amounted to $6 \%$.

Table 5. ANOVA

\begin{tabular}{|c|c|c|c|c|c|c|}
\hline Model & & $\begin{array}{l}\text { Sum } \\
\text { Squares }\end{array}$ & $\begin{array}{l}\text { of } \\
\mathrm{df} \\
\end{array}$ & Mean Square & $\mathrm{F}$ & Sig. \\
\hline \multirow[t]{3}{*}{1} & Regression & $1.206 \mathrm{E} 12$ & 2 & $6.031 \mathrm{E} 11$ & 4.347 & $.029^{\mathrm{a}}$ \\
\hline & Residual & $2.49 \mathrm{E} 12$ & 18 & $1.387 \mathrm{E} 11$ & & \\
\hline & Total & $3.704 \mathrm{E} 12$ & 20 & & & \\
\hline
\end{tabular}

Based on the results of $\mathrm{F}$ value amounted to $4,34>\mathrm{F}$ table 3.55 with level significant 0.029. This means Raw Palm Oil and Biofuel price has a significant effect on the 
production of Crude Palm Oil. This regression model explains that Raw Palm Oil and Biofuel prices in a manner simultaneous has significant influence to Crude Palm Oil production. The equation from the regression results can denote as follows;

Crude Palm Oil Production = 3,011.000 + 0.085 Raw Palm Oil - 46,674 Biofuel Price. If there is no increase in the use of Raw Palm Oil and prices Biofuel with constant level then there was 3.011 million of Crude Palm Oil production, if it occurs increase by using of Raw Palm Oil by 0.085 , then it will increase the production level with the amount of .085. is the opposite if Biofuel prices increase by 46,674 then there will be a decline of production level by 46.674 .

Wilmart Group will reduce biofuel usage if Biofuel price is increasing and as substitude, they will using fuels from waste of Crude Palm Oil production for efficiency production cost.

Research results from Hermawan, Edison and Damayanti (2015) also produce that production factors that in the form of raw material, capital and machine in a manner simultaneous have influence significant to Crude Palm Oil production while it partially only raw-material and capital that have influence which is significant towards Crude Palm Oil production, meanwhile machine haveno significant effect on Crude Palm Oil production.

According the results from Septian, Basri and Pailis (2015), test is simultaneous regression test (F test) showed raw materials, labor, and machine had a significant effect on Crude Palm Oil. Partial regression test ( $\mathrm{t}$ test) showed that the variables of raw materials and machinery had a positive and significant effect on the variable production of Crude Palm Oil. Petroleum prices have a real impact on the price of Indonesian Crude Palm Oil exports. If the price of oil increases, it will cause the price of Crude Palm Oil exports also to increase. The export price of Crude Palm Oil in addition is having a real impact on Crude Palm Oil export volume. This means that if the export price increases, in addition to causing an increase in the volume of the Indonesian Crude Palm Oil exported, it will also cause the price of Crude Palm Oil in the country (domestic) increased. Crude Palm Oil in addition to an output of the plantation company, it is also an input for the cooking oil company. Therefore, domestic Crude Palm Oil price changes will cause changes in the production of palm oil. From domestic Crude Palm Oil price has a significant influence on the production of palm oil. If the domestic Crude Palm Oil price increases it will lead to the decline of palm oil production (Murti,2017)

\section{Conclusion}

From the results research on PT. Wilmar, Composition Raw Palm Oil materials which use for production process is $66 \%$ from Raw Palm Oil that processed to produce Crude Palm Oil, while $34 \%$ is a waste form of empty bunches. Theres two type fuels which PT.Wilmar use for machinery, first is Biofuel and second one is waste from Raw $\mathrm{Palm}$ Oil. Usage of Biofuel for production procces is a policy from Wilmart Group, which is as main fuels to operate machinery with price range Rp. 7,072 to Rp. 9,348. Raw Palm Oil and Biofuel prices has significant influence to Crude Palm Oil production, while $t$ test show that Raw Palm Oil have influence against Crude Palm Oil production and Biofuel prices has no effect against Crude Palm Oil production.

Besides using Biofuel in producing, PT .Wilmar also using waste of Crude palm oil production as fuels for run the machinery. Waste of Crude palm oil production is generated through production process of Crude Palm Oil with composition 24\% from the purchasing price of Raw Palm Oil with price range Rp. 192 to Rp. 459

Table.6 Comparison Price and Fuel Usage

\begin{tabular}{lllll}
\hline Fuels & Production hour & Usage/month & Price & Total Cost \\
\hline Biofuel & 18 & 23.430 litre & Rp.8340 & Rp.6.279.090 \\
Waste of Raw & 18 & 4.192.814 litre & Rp.346 & Rp.2.686.507 \\
Palm Oil & & & & \\
\hline
\end{tabular}

Source : PT. Wilmar Nabati.2019 
Efficiency cost of Biofuel need implemented with using of waste from Raw $\mathrm{Palm}$ Oil because it can reduce the cost of production by Rp.3,592,583 in I (one) day. To Upgrade the results production, ingredients of fuels it must good quality so that can produce synergy in production process PT.Wilmar.

\section{Reference}

1. Anggoro, M.T. 2008. Metode Penelitian. UT . Jakarta.

2. Azwar. 2015 Dampak Perubahan Harga Crude Palm Oil (Crude Palm Oil) Dunia Terhadap Volume Ekspor Komoditas Kelapa Sawit Dan Erekonomian Indonesia (Pendekatan Vector Autoregression Analysis) Jurnal Info Artha Sekolah Tinggi Akuntansi Negara (STAN) Vol.I (13)

3. Bentivoglio.D, Finco.A, Bucci.G.2018. Factors Affecting the Indonesian Palm Oil Market in Food and Fuel Industry: Evidence from a Time Series Analysis. International Journal of Energy Economics and Policy, 8(5), 49-57.

4. Denny. M, Kusnadi.N, Tambunan.M, Firdaus.M. 2011. Dampak Kebijakan Pengembangan Bahan Bakar Nabati Terhadap Dinamika Harga Komoditas Pangan Dan Energi Nasional Dengan Pendekatan Model Sistem Dinamis .Indonesian Journal of Agricultural Economics. Volume 2, (2)

5. Direktorat Jendral Perkebunan.2019.Volume Produksi Crude Palm Oil 20002018.online.Available at http://lokadata.id/. accesed March 2019.

6. Ewaldo.E. 2015 Analisis ekspor minyak kelapa sawit di Indonesia e-Jurnal Perdagangan, Industri dan Moneter Vol. 3. (1)

7. Gasperz. V. 2005. Ekonomi Manajerial. PT.Gramedia.Jakarta

8. Ghozali I. 2006. Aplikasi Analisis Multivariat dengan Program SPSS. Semarang.Universitas Diponegoro

9. Hermawan.B, Edison, Damayanti.Y. 2015. Analisis Faktor - Faktor Yang Mempengaruhi Produksi Crude Palm Oil (Crude Palm Oil) Pada Pt.Satya Kisma Usaha Sungai Bengkal Mill Kabupaten Tebo.Sosio Ekonomika Bisnis Vol 18. (2)

10. Ismiasih.( 2017). Technical Efficiency Of Palm Oil Production In West Kalimantan. HABITAT, 28 (3), 91-98

11. Kantaporn C, Aree W, Songsak S, Chukiat C. 2012 Factors Affecting Palm Oil Price Based on Extremes Value Approach. International Journal of Marketing Studies; Vol. 4 ( 6)

12. Kementerian Pertanian.2018.Perkembangan Luas Perkebunan Sawit Indonesia 1980-2016.online. Available at http://www.pertanian.go.id/. accesed august 2018.

13. Kewinoto J.W, Sjahruddin M.M. 2015.Analisis pengaruh harga komoditas minyak kelapa sawit (CRUDE PALM OIL), tingkat inflasi, nilai tukar Rupiah dan volume penjualan komoditas (CRUDE PALM OIL) terhadap harga saham pada perusahaan penghasil kelapa sawit (CRUDE PALM OIL) yang terdaftar di Bursa Efek Indonesia. JOM FEKON .Vol. 2 (1)

14. Lumbantoruan D.H, Poerwanto, Tarigan U. 2013. Penentuan Jumlah Produksi Optimal Cpo Dengan Menggunakan Metode Goal Programming Pada Pabrik Kelapa Sawit PT. XYZ. e-Jurnal Teknik Industri FT USU Vol 3, No. 2

15. Maygirtasari.T, Yulianto.E, Mawardi.M.K. 2015. Faktor-Faktor Yang Mempengaruhi Volume Ekspor Crude Palm Oil (Crude Palm Oil) Indonesia. Jurnal Administrasi Bisnis (JAB).Vol. 25 (2) 
16. Murti.W. 2017.The Influence of Crude Oil Price in Biodiesel and its Implication on the Production of Palm Oil: The Case of Indonesia. European Research Studies Journal. Volume XX, Issue 2A,

17. Norhayanti M. Identifying Factors Affecting Palm Oil Prices Based On Grey Incidence Analysis International Journal of Academic Research in Business and Social Sciences, 8(11), 13-21.

18. Nugroho A.P.P, Fitriyanto D, Roesyadi A. 2014. Pembuatan Biofuel dari Minyak Kelapa Sawit melalui Proses Hydrocracking dengan Katalis Ni- $\mathrm{Mg} / \gamma-\mathrm{Al} 2 \mathrm{O} 3$. JURNAL TEKNIK POMITS Vol. 3, No. 2, (2014) ISSN: 2337-3539

19. Nugroho, H.B.A. 2005. Strategi Jitu Memilih Metode Statistik Penelitian dengan SPSS. Yogyakarta

20. Purba J.H.V, Hartoyo S. 2010. Dampak Kenaikan Harga Minyak Bumi Terhadap Permintaan Cpo Untuk Biodiesel Dan Beberapa Aspek Pada Industri Kelapa Sawit Indonesia. Jurnal Ilmiah Manajemen dan Akuntansi Fakultas Ekonomi (JIMAFE). 1.

21. Rahman A.K.A; Balu. N, Faizah.M.S.2013. Impact of Palm Oil Supply and Demand on Palm Oil Price Behaviour Oil Palm Industry Economic Journal Vol. 13 (1)

22. Rambe K.R*, Kusnadi N, Suharno.2019. Dinamika Kebijakan Pengembangan Biodiesel Berbahan Baku Kelapa Sawit Indonesia. Jurnal Sosial Ekonomi Pertanian. Vol. 15 (3)

23. Septian.E, Basri.S, Pailis.E.A.2015.Analisis Faktor-Faktor Yang Mempengaruhi Produksi Crude Palm Oil (Crude Palm Oil) Pt. Perkebunan Nusantara VI (Persero) Solok Selatan. Jom FEKON.Vol.2 (2).

24. Sugiyono, 2007. Metode Penelitian Bisnis, CV Alfabeta, Bandung

25. Syahril, Masbar.R, Syahnur.S, Majid.S.A, Zulham.T, Saputra.J, Badli.S, Irmayani. 2019. The Effect of Global Prices of Crude Palm Oil, Marketing Margins and Palm Oil Plantations on the Environmental Destruction: An Application of Johansen Cointegration Approach.International Journal of Energy Economics and Policy, , 9(4), 305-312

26. Latipah N, Sundaryono A, Elvia R.2017.Produksi Biofuel Dari Limbah Crude Palm Oil Dengan Katalis Berbasis Titanium Oksida Dan Implementasinya Pada Pembelajaran Kimia. Theses. 